\title{
Conceptual Design of an Unmanned Fixed-Wing Aerial Vehicle Based on Alternative Energy
}

\author{
Alan G. Escobar-Ruiz, ${ }^{1,2}$ Omar Lopez-Botello, ${ }^{2,3}$ Luis Reyes-Osorio, ${ }^{1}$ \\ Patricia Zambrano-Robledo, ${ }^{1,2}$ Luis Amezquita-Brooks $\mathbb{D}^{1},{ }^{1}$ and Octavio Garcia-Salazar ${ }^{1}{ }^{1}$ \\ ${ }^{1}$ Universidad Autonoma de Nuevo Leon, Facultad de Ingenieria Mecanica y Electrica, Centro de Investigacion e Innovacion en \\ Ingenieria Aeronautica, UANL-FIME-CIIIA, Apodaca, Nuevo Leon, Mexico \\ ${ }^{2}$ Laboratorio Nacional de Manufactura Aditiva y Digital, Mexico \\ ${ }^{3}$ Tecnologico de Monterrey, Escuela de Ingenieria y Ciencias, Monterrey, Nuevo Leon, Mexico
}

Correspondence should be addressed to Octavio Garcia-Salazar; octavio.garcias@uanl.mx

Received 21 May 2019; Revised 15 September 2019; Accepted 17 September 2019; Published 14 November 2019

Academic Editor: Hikmat Asadov

Copyright (C) 2019 Alan G. Escobar-Ruiz et al. This is an open access article distributed under the Creative Commons Attribution License, which permits unrestricted use, distribution, and reproduction in any medium, provided the original work is properly cited.

\begin{abstract}
This paper focuses on the aerodynamics and design of an unmanned aerial vehicle (UAV) based on solar cells as a main power source. The procedure includes three phases: the conceptual design, preliminary design, and a computational fluid dynamics analysis of the vehicle. One of the main disadvantages of an electric UAV is the flight time; in this sense, the challenge is to create an aerodynamic design that can increase the endurance of the UAV. In this research, the flight mission starts with the attempt of the vehicle design to get at the maximum altitude; then, the UAV starts to glide and battery charge recovery is achieved due to the solar cells. A conceptual design is used, and the aerodynamic analysis is focused on a UAV as a gliding vehicle, with the calculations starting with the estimation of weight and aerodynamics and finishing this stage with the best glide angle. In fact, the aerodynamic analysis is obtained for a preliminary design; this step involves the wing, fuselage, and empennage of the UAV. In order to achieve the preliminary design, an estimation of aerodynamic coefficients, along with computational fluid dynamics analysis, is performed.
\end{abstract}

\section{Introduction}

In the past years, Unmanned Aerial Vehicles (UAVs) have attracted the attention of scientists and engineers who have been working on their design and development in order to increase the autonomy and endurance of these vehicles. Grouped in two categories, the UAVs can be seen as rotary-wing and fixed-wing vehicles, depending on the task to be carried out [1]. One of the main disadvantages of UAVs is flight autonomy, which means that these vehicles are limited to missions where a high range is required due to their battery-based power system [2]. It is desired that the UAV performs autonomous flights in civil applications. In this sense, avionics need to be upgraded in order to perform autonomous flights $[3,4]$. In [5], the authors presented a simultaneous small UAV and autopilot system designed to improve the autonomous flight performance of a UAV. The mathematical equations are presented in detail and linearized in state-space models of the UAV for several flight conditions. A PID-based hierarchical autopilot system is studied and validated in a closed-loop system. In [6], the authors redesigned the nosecone and tailcone shapes of a tactical UAV in order to improve the lift/drag ratio. In addition, an active flow control is built on its wing for increasing the maximum lift/drag ratio. In [7], a design of the simultaneous longitudinal and lateral flight control systems for both passive and active morphing tactical unmanned aerial vehicles (TUAVs) was presented in order to maximize the autonomous flight performance. 
In the works of the aerodynamic design of solar UAVs, for example, a conceptual design method for a hybrid solarpowered aircraft was presented in [8], which uses a propulsion system that was a hybrid between an internal combustion engine and an electric motor. In [9], authors carried out solar radiation research where they collected data in 12 cities around the world indicating that the duration of sunlight is as important as radiation for the performance of a UAV powered by solar cells; therefore, the cities closest to the Ecuador line have the advantage of obtaining more radiation and sunlight. In [10], the authors presented a method to calculate the number of solar cells required to obtain the power necessary to have a straight-and-level flight as well as the energy efficiency of the solar cells. In [11], the authors presented a flight dynamics simulation using the simplified $2 \mathrm{DoF}$ model and proposed a maximum altitude and minimum altitude to obtain the necessary energy to maintain flying. The altitude and payload mass have an influence on the size and design of the aircraft as shown in [12]. In [13], the authors discussed the factors that affect the energy storage as the duration of solar irradiation, the charging rate, the energy density of the rechargeable battery, and the initial altitude of the aircraft. In this sense, a comparison of different methods to extract and store energy for solar-powered aircraft was presented in [14].

In [15], a comparison was performed between the results obtained from XFOIL and ANSYS Fluent for a low Reynolds number where graphs of XFOIL airfoil simulation are compared to select an adequate airfoil. In [16], the authors presented a simulation of an airfoil using the Spalart-Allmaras turbulence model for computing lift, drag, and pressure coefficients. In [17], the Spalart-Allmaras model was compared with experimental and numerical results for turbulent flow on a prismatic cylinder demonstrating that this model can be effective and have potential for aerodynamic coefficient estimation.

Thus, the main purpose of this research is to design a UAV in order to obtain a glide stage which allows the battery to recover the energy based on the array of solar cells. In addition, this paper presents the design of solar-powered UAVs for high-altitude and straight-and-level flight; it means a flight without interruptions. The principal contributions of this work are as follows:

(i) The conceptual and preliminary design of a solarpowered UAV as a glider is proposed

(ii) The computational fluid dynamics analysis is presented

The methodology begins with the weight estimation and aerodynamic calculations to obtain the best glide angle, then the preliminary design and the verification of the calculations with computational fluid dynamics analysis are performed. The benefits of solar energy are used to charge the battery while it is in gliding mode; it means that when making the change to an aircraft powered by an electric motor, the battery comes into operation, providing the system with maximum reliability and versatility.

\section{Conceptual and Preliminary Design of the UAV}

The design requirements to evaluate and configure structural components of an aircraft include airfoil, wing position, size, and type of wing [18]. The methodology used in this work (see Figure 1) starts with the flight mission and evaluation of the atmospheric conditions; for aerodynamic analysis, two phases of the conceptual design were defined as follows: (i) the main wing and (ii) the elevator. The study continues with the preliminary design proposing a 3D model, and it finishes with a computational fluid dynamics analysis. If it does not satisfy the required results, the process is modified returning to the preliminary design.

The UAV flight mission is illustrated in Figure 2; the vehicle flies and rises to a maximum altitude at which time the battery supplies energy to the main motor to propel the aircraft. Following this stage, the motor will be turned off, and then the vehicle will have a gliding flight. During the glide time, the solar cells will convert the solar energy to electric power so that the glide angle provides a greater coverage [19].

The ideal glide angle and climb angle are defined based on aerodynamic calculations in order to demonstrate the time at which a flight cycle is performed as proposed on the flight mission shown in Figure 2. Within a time of 5 minutes, a minute of the climb phase is performed followed by 4 minutes of the gliding phase. During the gliding phase, the charging of the battery is achieved as a result of the exposition of the solar cells.

The selection of atmospheric conditions is assumed at sea level from the International Standard of Atmosphere; that is, an invariant terrestrial atmospheric model created by the International Civil Aviation Organization (ICAO) [20]. In addition, it is important to identify the air density of the UAV to estimate the aerodynamic coefficients and obtain a preliminary design. A maximum altitude of $122 \mathrm{~m}$ is defined, and it is considered that in the troposphere $(0-11 \mathrm{~km})$ the temperature decreases $-6.5^{\circ} \mathrm{C}$ every $1000 \mathrm{~m}$ [20]. The calculation of atmospheric pressure with respect to the maximum altitude and the temperature of operation is applied to obtain the air density at which this UAV will fly in minimum and maximum altitude as illustrated in

$$
\rho=\frac{P}{R T}=\frac{P}{R\left(T_{0}-0.0064 h\right)} .
$$

A weight estimation is evaluated in the design process (see Table 1). In the estimation of the weight of the UAV [21], for future work, an ABS material is considered which has a density of $1.1 \mathrm{~g} / \mathrm{cm}^{3}$; for that reason, the conceptual and preliminary design is evaluated with a uniform mass.

2.1. Aerodynamic Calculations. At this stage, the aerodynamic calculations are performed considering the dynamic behavior of the fluid on the aircraft and giving as a possibility the correction of the conceptual design due to undesired aerodynamic results or stability problems [22]. 


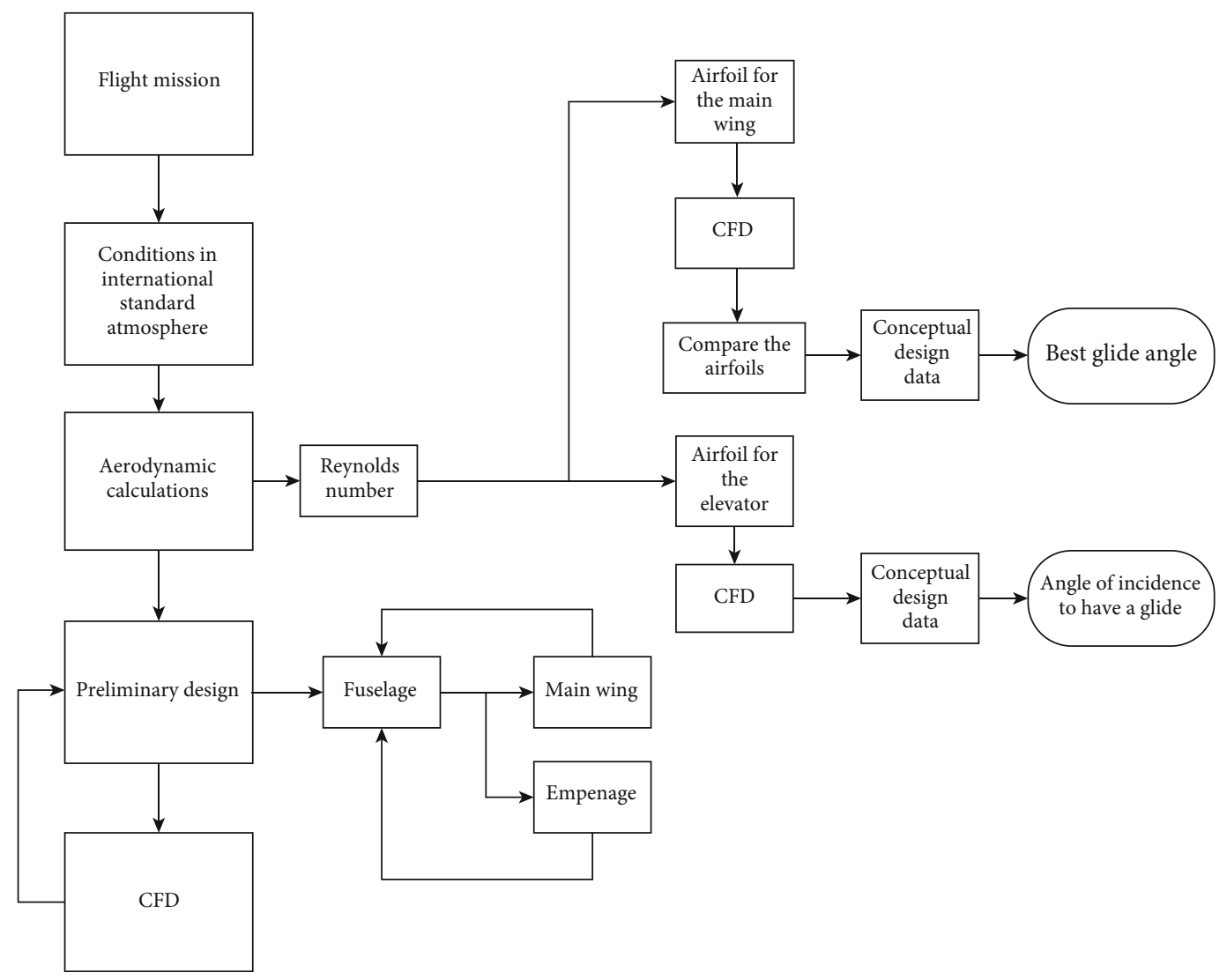

Figure 1: Flow chart of the design of a UAV using alternative energy.

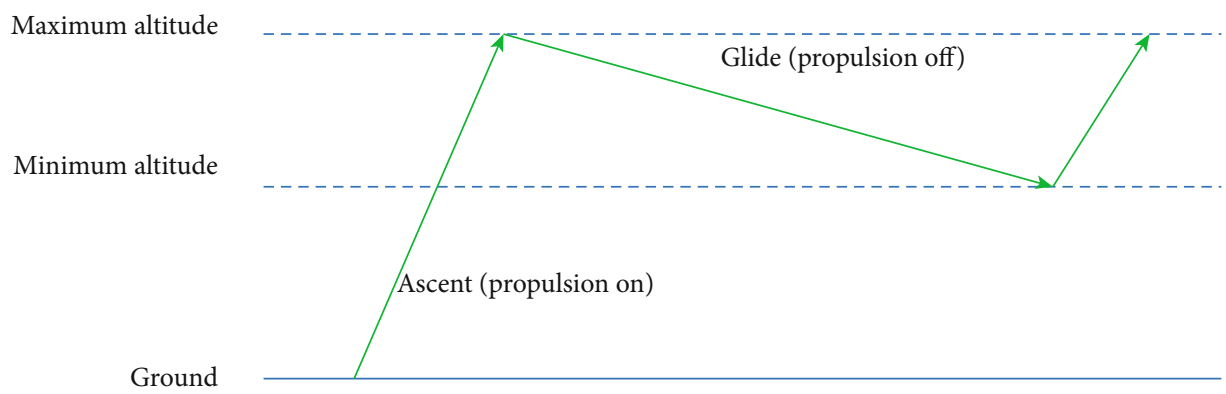

Figure 2: Flight mission of the UAV.

TABLE 1: Weight estimation.

\begin{tabular}{lccc}
\hline Item & Quantity & $\begin{array}{c}\text { Unit weight } \\
(\mathrm{kg})\end{array}$ & $\begin{array}{c}\text { Total weight } \\
(\mathrm{kg})\end{array}$ \\
\hline Battery LiPo3s & 1 & 0.188 & 0.188 \\
Servomotor & 4 & 0.0098 & 0.0392 \\
Main engine & 1 & 0.055 & 0.055 \\
ESC & 1 & 0.029 & 0.029 \\
Flight computer & 1 & 0.038 & 0.038 \\
Solar cells & 20 & 0.022 & 0.44 \\
GPS & 1 & 0.026 & 0.026 \\
$\begin{array}{l}\text { Approximate weight } \\
\text { of the UAV }\end{array}$ & 1 & 3.7 & 3.7 \\
\hline
\end{tabular}

For this vehicle, the main wing carries the solar cells in the upper surface and it generates the aerodynamic force in the air [23]. Aerodynamic analysis was carried out to obtain a long range and an increase in efficiency; thus, the number of solar cells defines the wing dimension. Having a solar cell with a dimension of $19.2 \mathrm{~cm} \times 9.5 \mathrm{~cm} \times 0.5 \mathrm{~mm}$, with an array of 20 photovoltaic cells, covers an area of $0.44 \mathrm{~m}^{2}$ and a chord of $c=0.27 \mathrm{~m}$ is proposed. The proposed solar cells have the capability to produce $2 \mathrm{~V}_{\mathrm{DC}}$ and $0.5 \mathrm{~A}$. The objective is to obtain $20 \mathrm{~V}_{\mathrm{DC}}$ with two arrays of 10 solar cells connected in series, as it is well known that the voltage is added for connection in series. Then, the two arrays obtained are connected in parallel to sum the current to obtain $1 \mathrm{~A}$. 


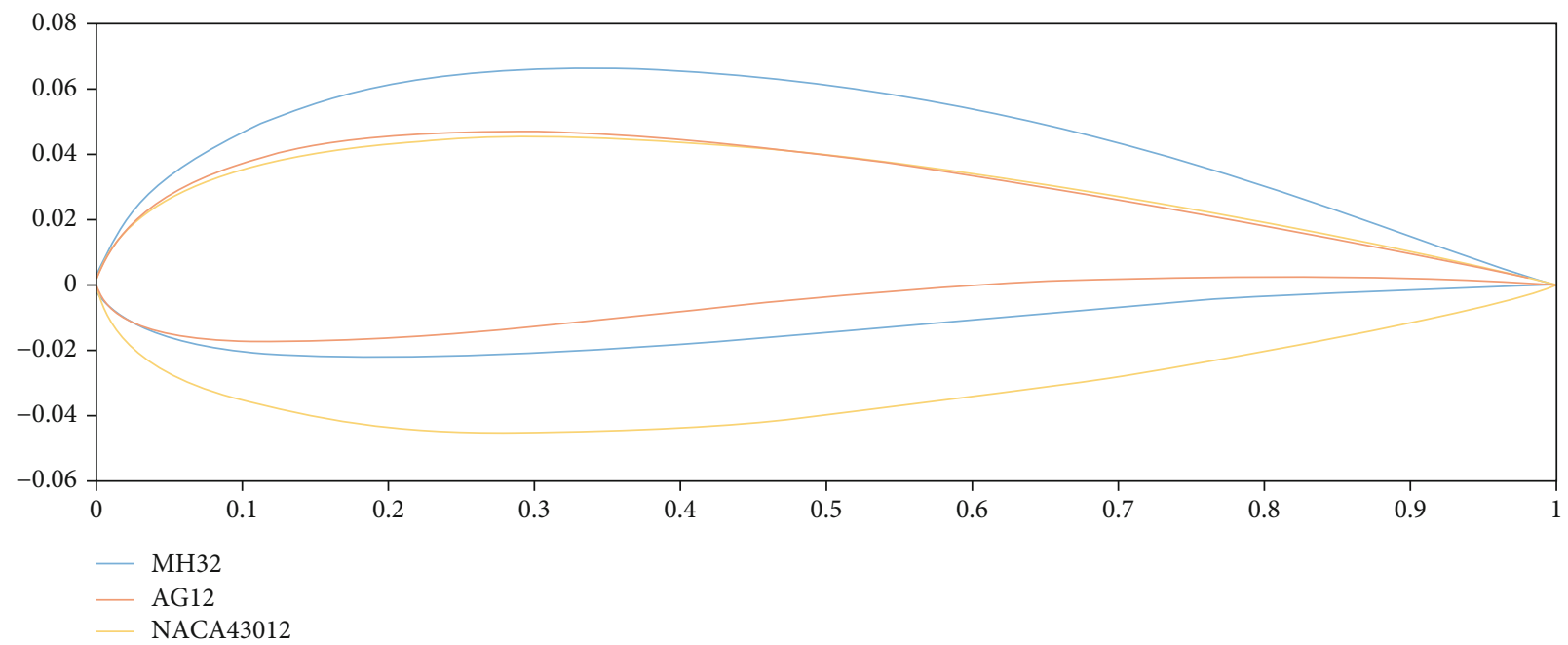

FIgUre 3: Aerodynamic airfoils selected for comparison.

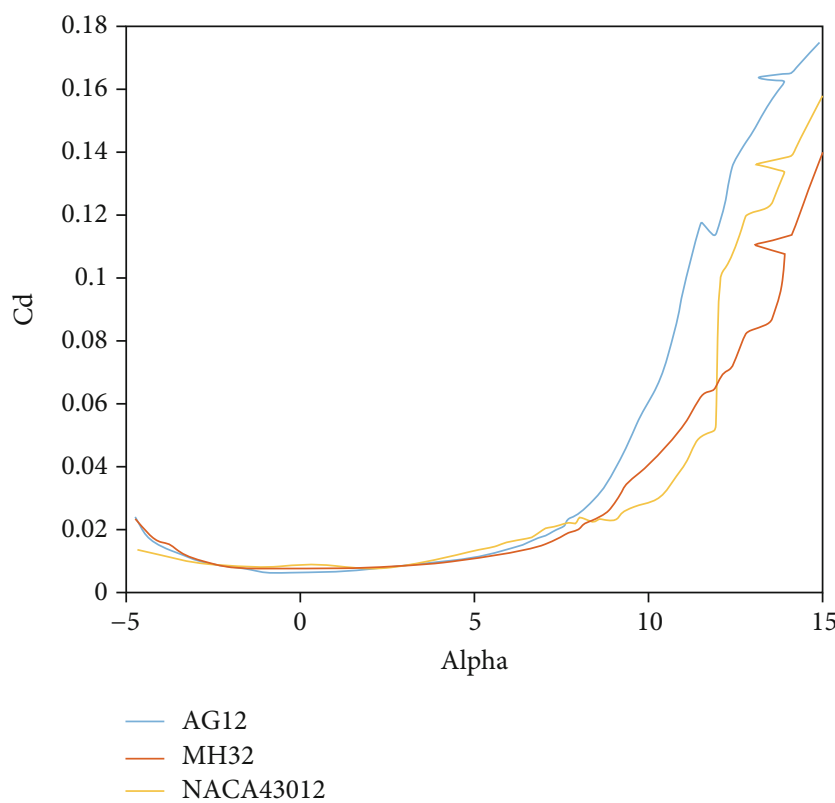

(a)

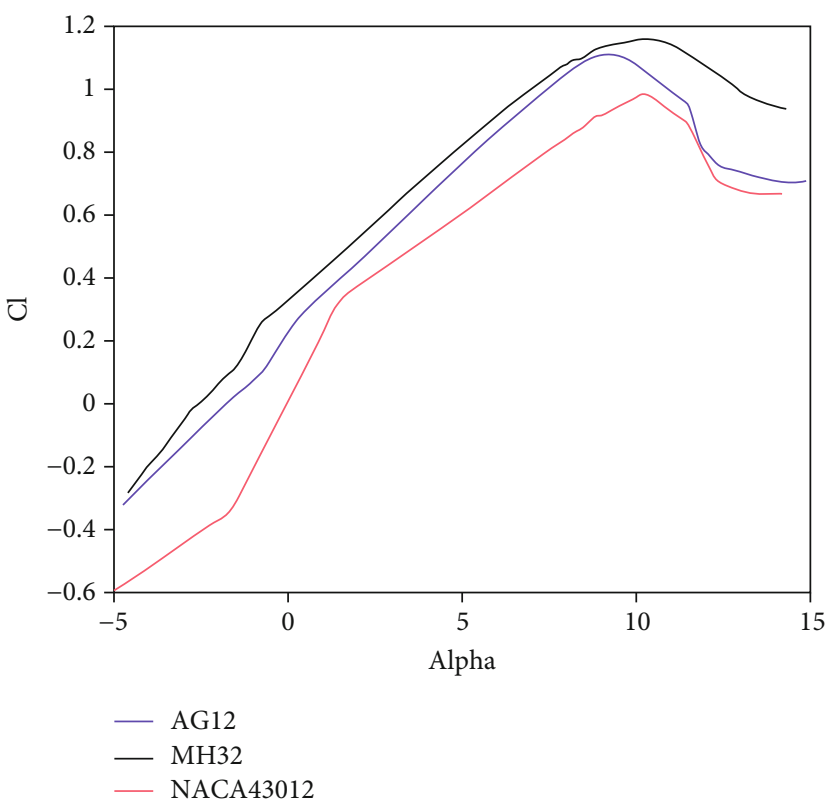

(b)

Figure 4: (a) Coefficient of drag vs. angle of attack. (b) Coefficient of lift with respect to angle of attack.

The aerodynamic design considers the selection of an aerodynamic airfoil, and the following criteria is considered: an airfoil with a minimum drag coefficient as well a maximum lift coefficient, which means the highest lift-to-drag ratio. An additional parameter considered for this UAV is to have the lowest pitching moment coefficient [24]. Based on the previous description, an aerodynamic airfoil is proposed that operates at low Reynolds numbers; thus, the proposed airfoils are AG12, MH32, and NACA43012 (see Figure 3).

Selected airfoils were evaluated with respect to the Reynolds number operation. In Figure 4(a), the coefficient of drag with respect to the angle of attack is depicted. A comparative analysis of previous airfoil results indicates a similarity at small angles of attack; however, evaluating the results at high angles of attack, the graphs have a different magnitude showing that the Mh32 airfoil provides the best behavior at a high angle of attack. In Figure 4(b), the lift coefficient obtained from all the airfoils is evaluated around the maximum lift and the stall angle, with all the airfoils having a similar stall angle at around $10 \mathrm{deg}$. In fact, the difference comes in the magnitude, with the Mh32 airfoil having the best behavior.

The best lift-to-drag ratio is shown in Figure 5(a); comparing the airfoils, NACA43012 does not have the expected behavior due to the low ratio. The Mh32 presents a similar magnitude as AG12. In Figure 5(b), a comparison of $\mathrm{Cl} / \mathrm{Cd}$ with respect to the angle of attack is 


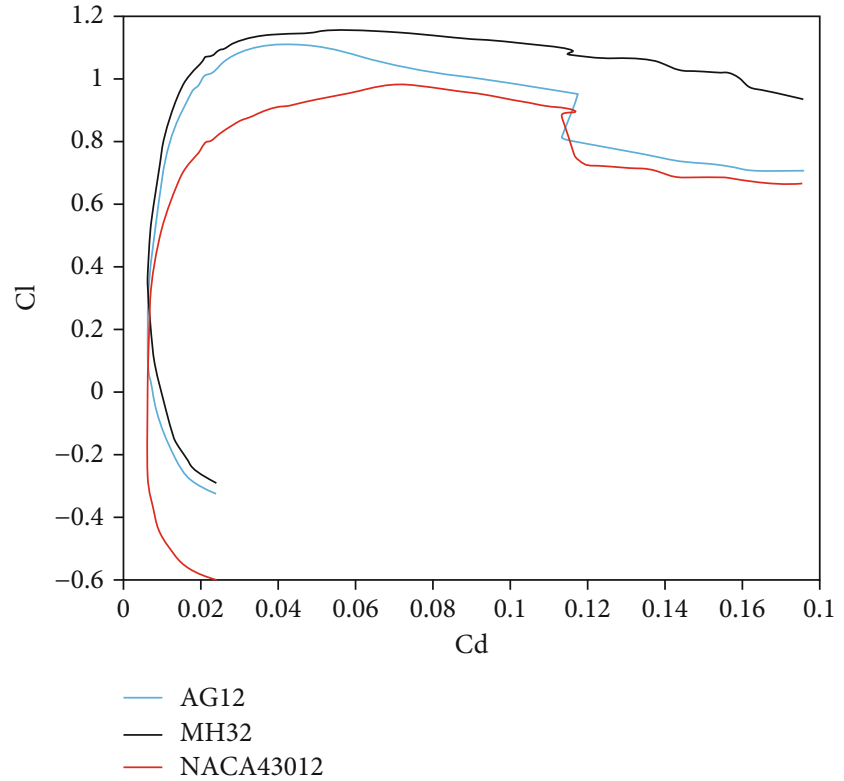

(a)

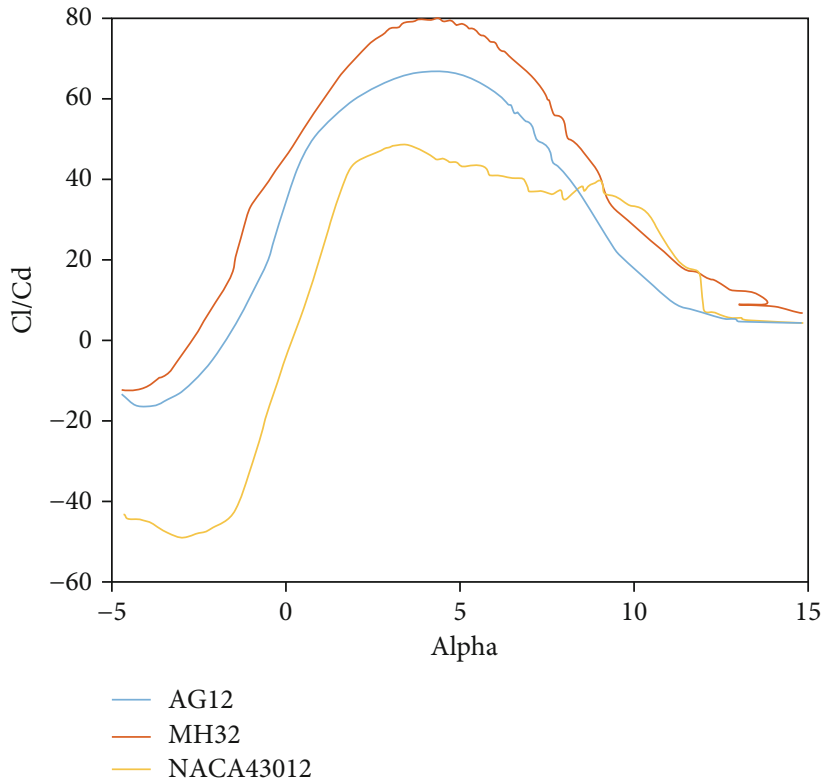

(b)

Figure 5: (a) Coefficient of drag with respect to coefficient of lift. (b) $\mathrm{Cl} / \mathrm{Cd}$ vs. angle of attack.

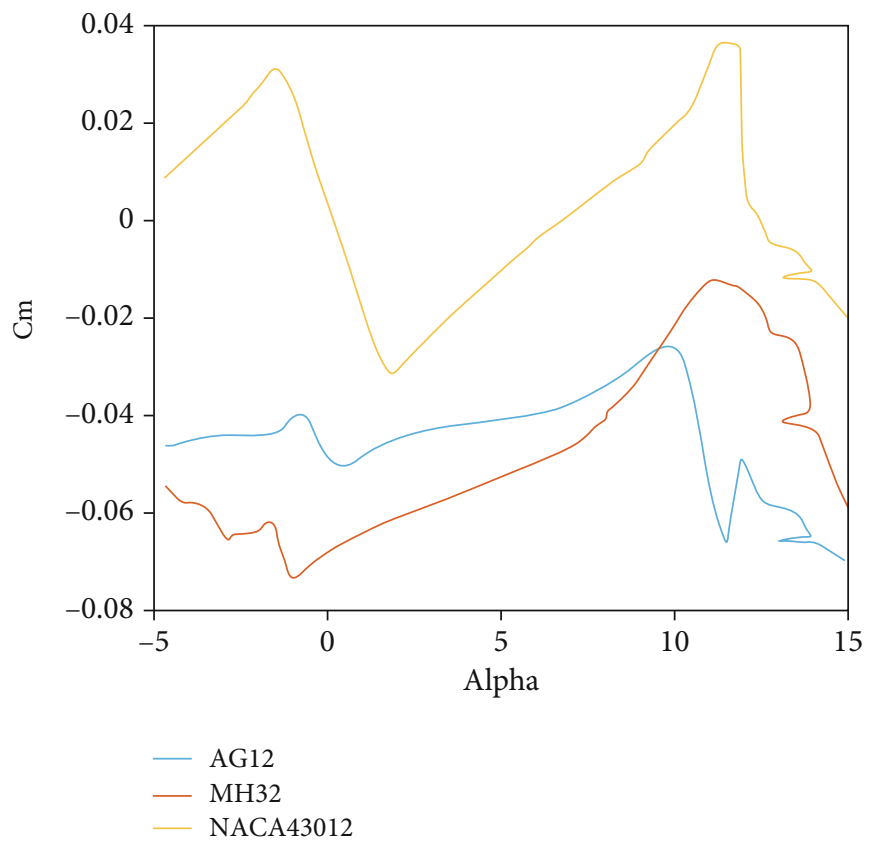

FIgURE 6: Coefficient of pitching moment.

presented having a similar magnitude of $\mathrm{Cl} / \mathrm{Cd}$; the observed difference is that the amplitude of the graph is greater than that of the Mh32 airfoil. The AG12 airfoil presents the best coefficient of pitching moment which has the lowest magnitude as shown in Figure 6. This coefficient influences the glide mode.

The selected airfoil based on the previous comparison is that of MH32. Specific requirements of the aircraft, as well as its mission of flight, aerodynamic wing chord, kinematic viscosity, and the Reynolds number with which the vehicle will operate on are shown in Table 2.

For wings with a nonelliptical distribution, the value of the induced angle of attack is modified with the Oswald efficiency factor [22]. With a mass estimation of the vehicle, the best glide angle that is selected in the second stage of flight can be obtained. Choosing the MH32 airfoil for the main wing of the vehicle, a conceptual design data is proposed (see Table 2). 
TABle 2: Conceptual design data.

\begin{tabular}{lc}
\hline Parameter & Value \\
\hline$S$ & $0.74 \mathrm{~m}$ \\
$W$ & $4.5152 \mathrm{~kg}$ \\
$\mathrm{AR}$ & 12.35 \\
$C_{D_{0}}$ & 0.009 \\
$e$ & 0.7477 \\
$h_{\max }$ & 122 \\
$\varphi$ & 0 \\
$\mathrm{MAC}$ & $0.2446 \mathrm{~m}$ \\
$v_{0}$ & $1.46 \times 10^{-5} \mathrm{~m}^{2} / \mathrm{s}$ \\
$R_{e}$ & $257,835.61$ \\
\hline
\end{tabular}

TABle 3: Conceptual design data for elevator.

\begin{tabular}{lc}
\hline Parameter & Value \\
\hline$C_{E}$ & $180 \mathrm{~mm}$ \\
$b_{E}$ & $640 \mathrm{~mm}$ \\
$S_{E}$ & $0.12 \mathrm{~m}^{2}$ \\
$l_{E}$ & $700 \mathrm{~mm}$ \\
\hline
\end{tabular}

The stall velocity is $V_{s}=9.4 \mathrm{~m} / \mathrm{s}$, which is the minimum velocity in which the UAV can fly [25]. In this case, the weight estimation and the simulation of the airfoil MH32 are used to obtain the required parameters. In order to obtain the best glide angle, the true air speed is TAS $=13.8159 \mathrm{~m} / \mathrm{s}$, which is the relative speed at which the vehicle is operating with respect to the density of the air [26].

One of the main considerations in this work is to obtain the best glide angle that is employed in the glide phase, and it will provide the highest lift-to-drag relation and a stable static of flight for the UAV. Thus, considering equation (2), the best glide angle is $-2.01 \mathrm{deg}$ [19].

$$
\gamma=a \sin \left(-\sqrt{\frac{4 C_{D_{0}}}{\pi e \mathrm{AR} \cos ^{2}(\phi)+4 C_{D_{0}}}}\right) .
$$

For the elevator, the symmetrical airfoil NACA0010 is proposed (see Table 3). The calculation of the moment for the UAV is based on a glide around the best glide angle, in contrast with the classic analysis where it is designed to have a straight-and-level flight [24, 27].

$$
\begin{gathered}
\sum M_{\text {C.G. }}=0, \\
M_{w_{0}}+M_{L_{w}}+M_{L_{E}}+M_{E_{0}}=0, \\
\frac{1}{2} \rho \operatorname{TAS}^{2} S_{w} C_{m_{w}} \bar{C}_{w}+\frac{1}{2} \rho \operatorname{TAS}^{2} S_{w} C_{L_{w}} l_{w} \\
+\frac{1}{2} \rho \operatorname{TAS}^{2} S_{E} C_{L_{E}} l_{E}+\frac{1}{2} \rho \operatorname{TAS}^{2} S_{E} C_{m_{E}} \bar{C}_{E} .
\end{gathered}
$$

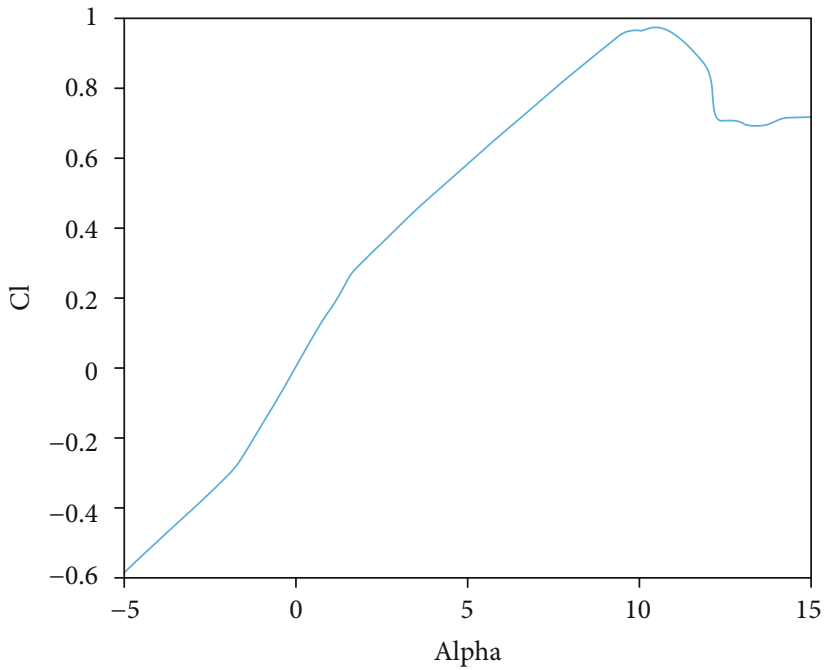

FIGURE 7: Lifting coefficient of the profile NACA0010.

Substituting values and simplifying the lift coefficient of the elevator from equation (5), the coefficient of the elevator in a static flight of glide mode is $C_{L_{F}}=0.0125$. The graph of the lift coefficient of the NACA0010 airfoil used for the elevator is presented in Figure 7. The lift coefficient value in this graph corresponds to an alpha angle which is the incidence angle of the elevator of $2.2 \mathrm{deg}$. This condition will have a statically stable glide.

One of the principal requirements established for the vehicle is to define an area for the installation of solar cells; thus, a design is considered for a straight wing as a root, ending in a trapezoidal shape. This area is covered by solar cells (see Figure 8). This allows the aircraft a low resistance to advance at the tips, high maneuverability, and high speed $[21,25]$.

The fuselage has two functions, to carry the payload and to assemble the main wing with the principal structure. An assembly that is incorporated into the fuselage and joined with screws to prevent movement is proposed (see Figure 9).

A type " $\mathrm{H}$ " empennage was selected since the horizontal stabilizer is located in undisturbed flow regions during flight operation. The fuselage is assembled with the empennage using aluminum tubes (see Figure 10).

Figure 11 depicts the estimated solar irradiation for a flight of the vehicle. The evaluation includes parameters of the specific time of day, the date of the year, and the latitude and longitude coordinates [9]. The magnitude of solar radiation entering the Earth is shown in $[28,29]$. Based on equation (6), the solar irradiation is estimated in the city of Monterrey, Nuevo Leon, Mexico, where the flight tests of the UAV are planned [30]. The variables DN and SolAlt involve the day of the year and the latitude and longitude of the place:

$I_{r_{\max }}=\frac{(1+0.033 \cos (0.017203 \mathrm{DN}(\pi / 180)) \sin (\operatorname{SolAlt}(\pi / 180)))}{3.6(1000) / 4.8708}$. 


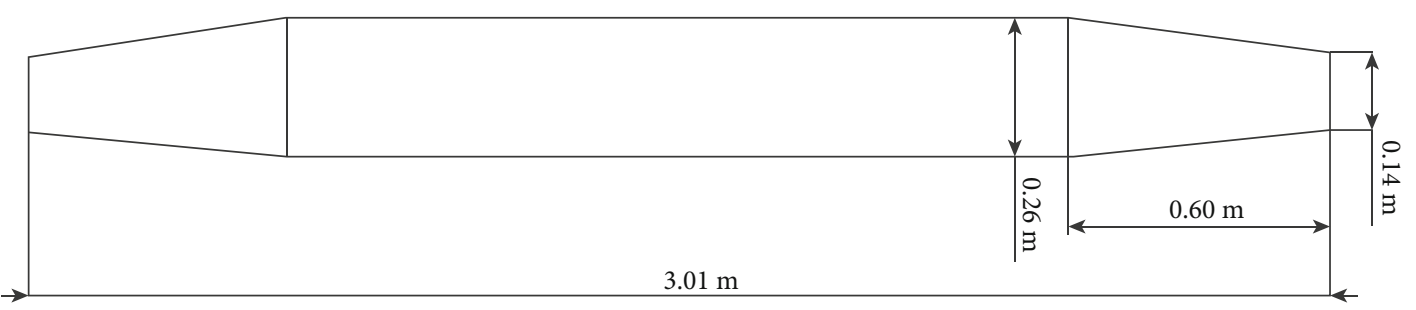

Figure 8: Wing shape and dimensions.
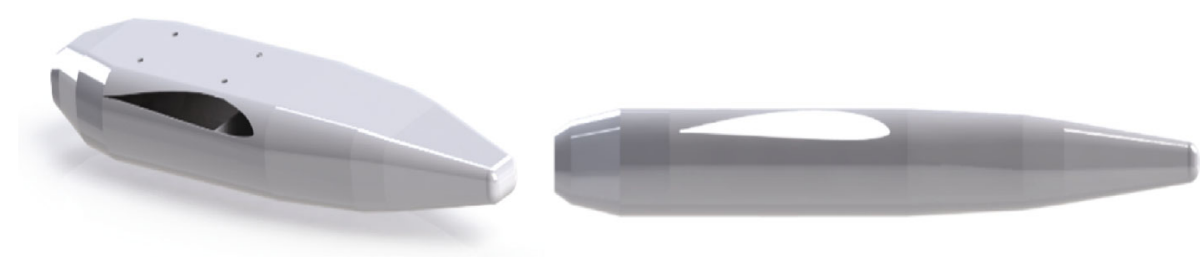

FIgURE 9: Preliminary design of the fuselage.
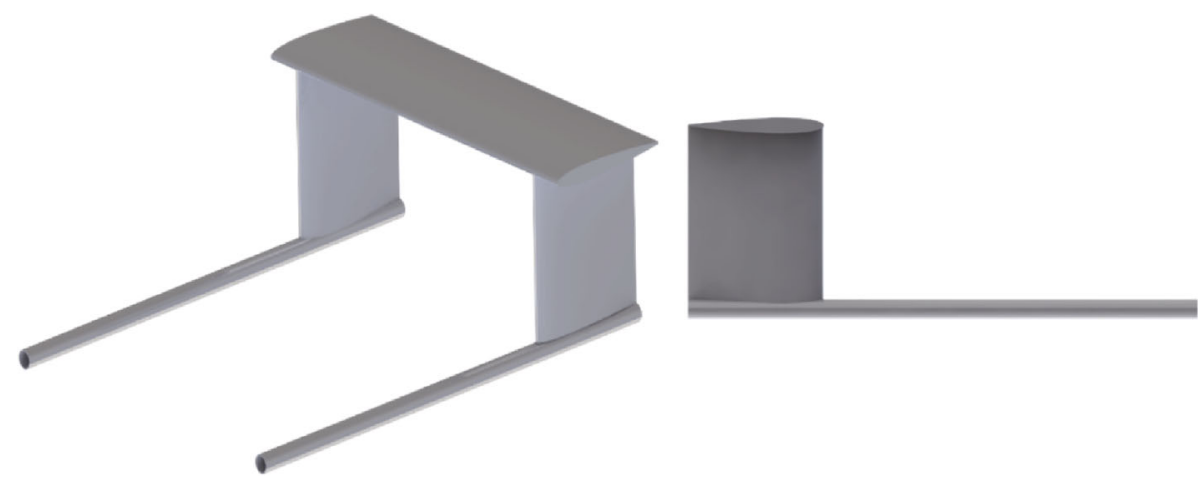

FIgURE 10: Preliminary design of the empennage.

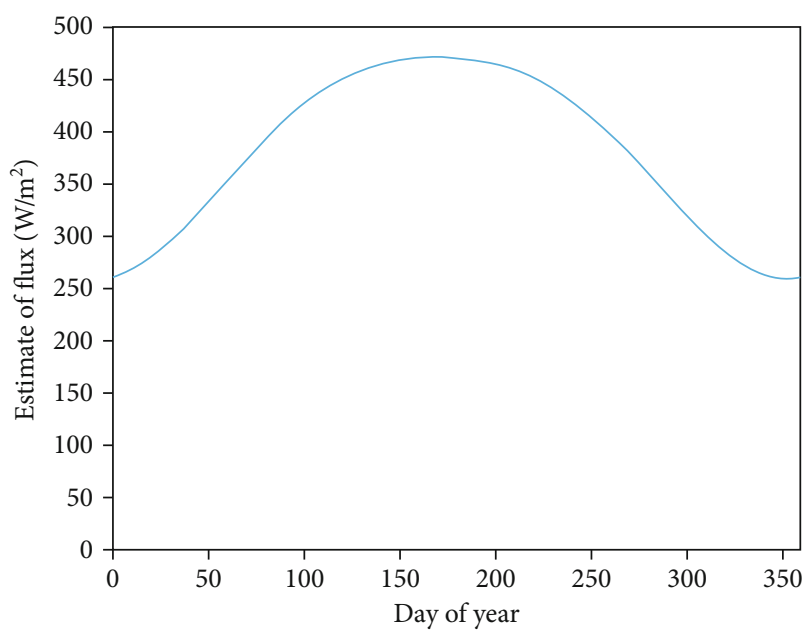

FIGURE 11: Estimate of radiative fluxes in Monterrey, Nuevo Leon, Mexico.

\section{Simulation of the UAV Based on the CFD Tool}

The numerical analysis is developed using the ANSYS Fluent software. Computational fluid dynamics can be applied to observe the behavior of a fluid around the surface of the main wing $[8,21]$. The first step of the numerical analysis considers importing the main wing geometry that is used as illustrated in Figure 12(a), then the application of a flow domain around the wing is shown in Figure 12(b). This stage is relevant since by defining this volume, the fluid interacts with the aircraft, obtaining as a result the coefficients as well as the vortices produced by the vehicle.

Figure 13 shows the meshing of the domain of the fluid and the refinement in the area of interest close to the wing, with a minimum element size of $2 \mathrm{~mm}$. Consequently, orthogonal quality has a maximum of 0.99787 with an average of 0.86498 and a minimum of 0.19818 . Skewness has a maximum of 0.84685 with a minimum of $6.5293 \times 10^{-5}$ and an average of 0.21887 . From [31], it is shown that an 


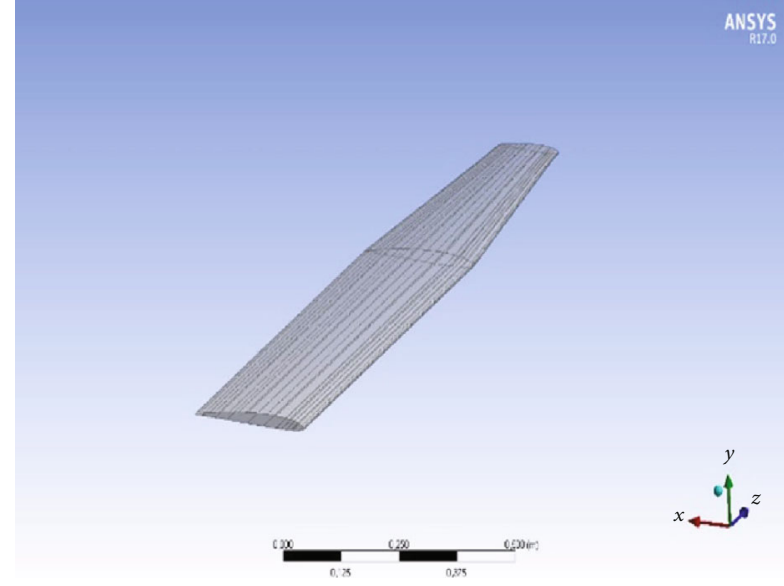

(a)

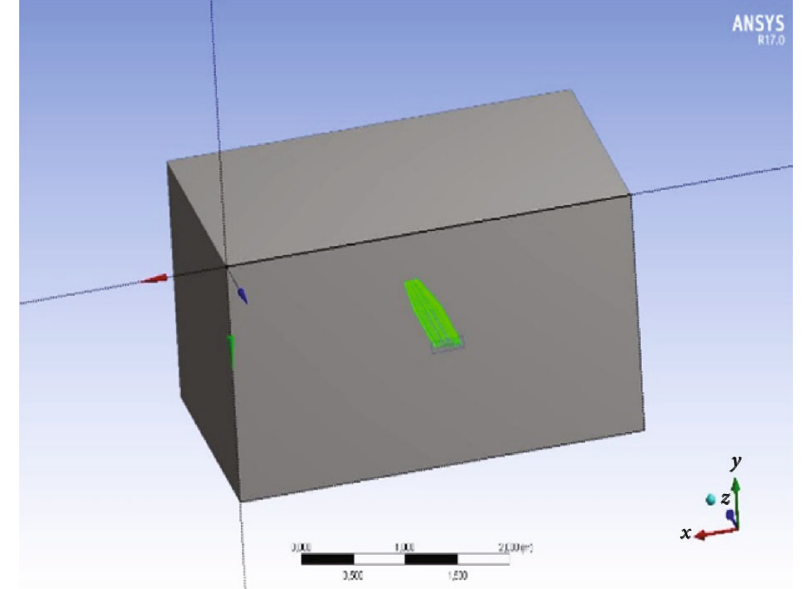

(b)

Figure 12: (a) Main wing of the vehicle imported in ANSYS Workbench. (b) Workflow domain.

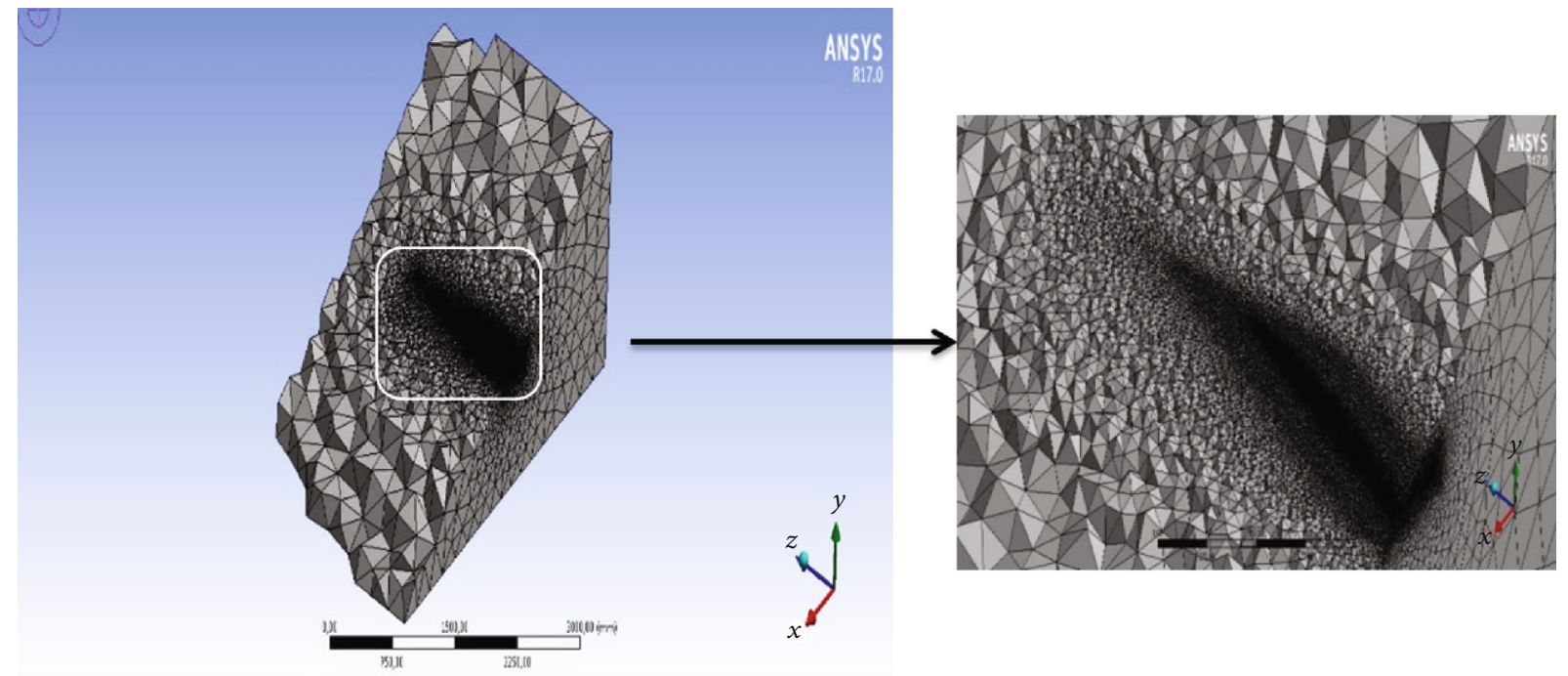

Figure 13: Mesh of the domain of the fluid and a zoom of the area of interest.

orthogonal mesh quality, equal to one, is found to obtain a fine aerodynamic performance.

For the simulation, the parameters were established in order to obtain the performance of the UAV. An absolute velocity in a stable time is considered using a SpalartAllmaras model [8], with a fluid with a density of $1.225 \mathrm{~kg} / \mathrm{m}^{3}$ and a viscosity of $1.7894 \times 10^{-5} \mathrm{~kg} / \mathrm{ms}$. The pressure on the wing is shown in Figure 14(a). In Figure 14(b), it is illustrated that the high pressure obtained is in the leading edge. Figure 15(a) shows the air velocity over the wing as well as the vortices that are produced in the wing over the air. The results of the lift produced by all the angles of attack are illustrated in Figure 15(b). A shift of angle of attack is performed, obtaining a lift coefficient of the simulated wing as illustrated in this figure, and a stall angle around 14 deg is shown; this angle must be avoided in flight in order to decrease the lift and its stability.

The design of the vertical stabilizer is based on the air flow; thus, the horizontal stabilizer is located in undisturbed flow regions during flight operations. The value of the angle of attack is around $5 \mathrm{deg}$, and the flow does not affect the operation (see Figure 16(a)). The angle of attack presented is -2 deg which performs the glide mode, as shown in Figure 16(b). These are the set of angles that the vehicle operates to rise to the maximum altitude and to glide to the minimum altitude, validating the flow over the horizontal stabilizer.

The presented work finishes with the final design of the vehicle that involves all the elements calculated and simulated as shown in Figure 17. To validate the study of this work, the vehicle will be manufactured based on an additive manufacturing.

\section{Solar Cells}

As part of the validation of the solar system, the voltage was measured throughout the day as shown in Figure 18, in 


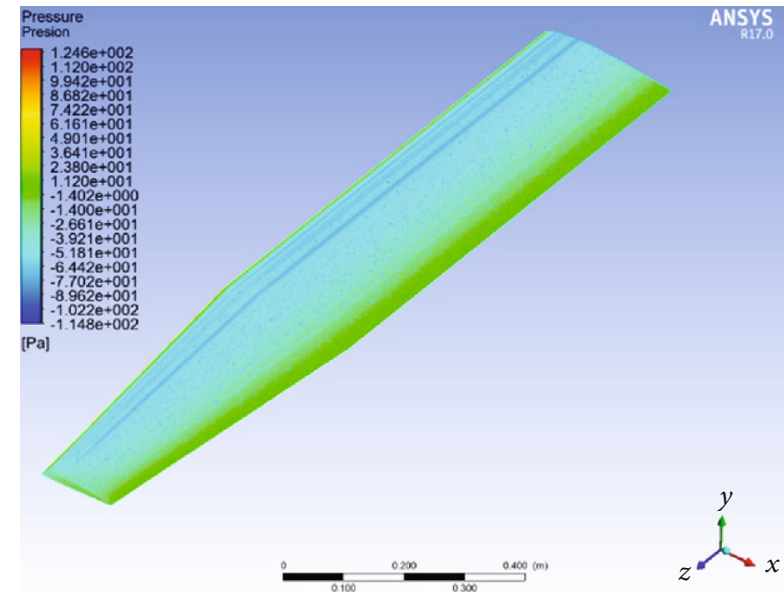

(a)

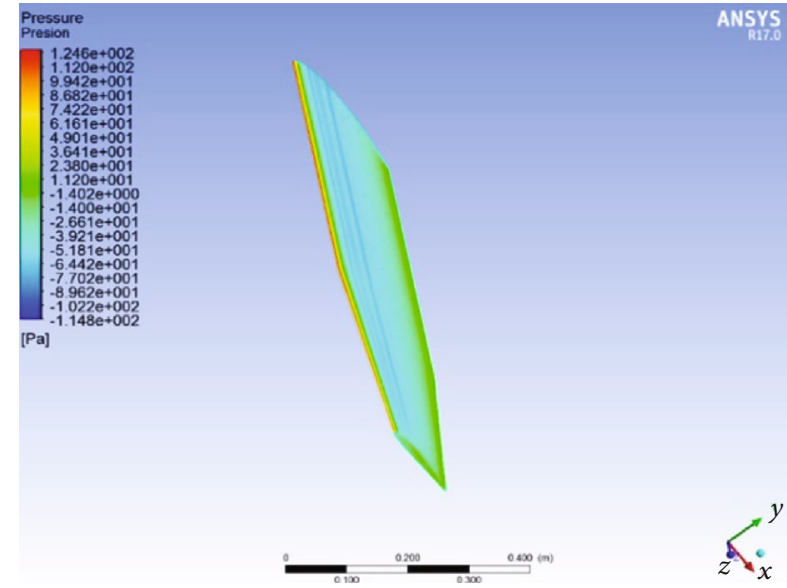

(b)

Figure 14: (a) Pressure on the main wing. (b) Pressure on the leading edge of the wing at an angle of attack of $12 \mathrm{deg}$.

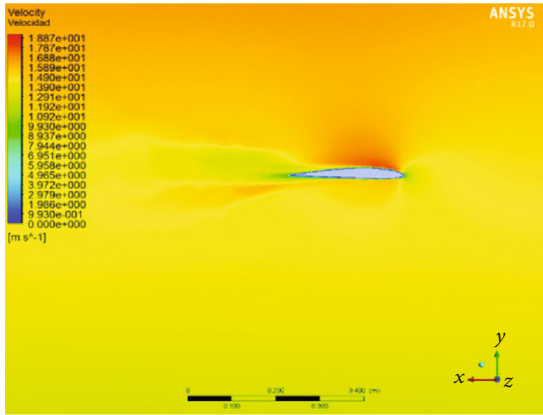

(a)

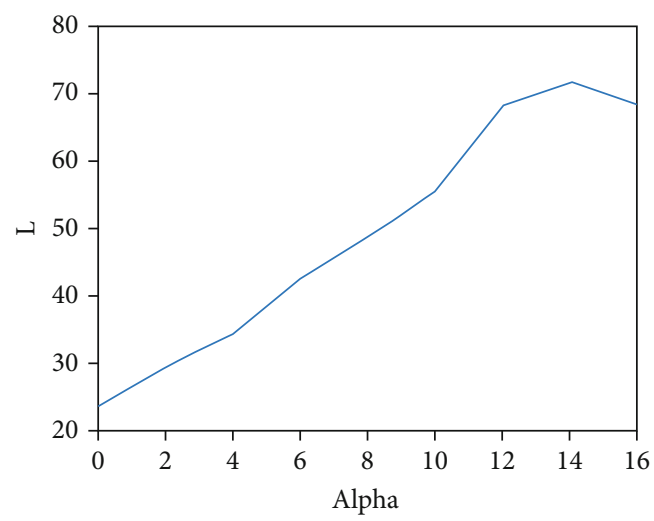

(b)

FIGURE 15: (a) Air velocity over the wing. (b) Lift produced by the wing.

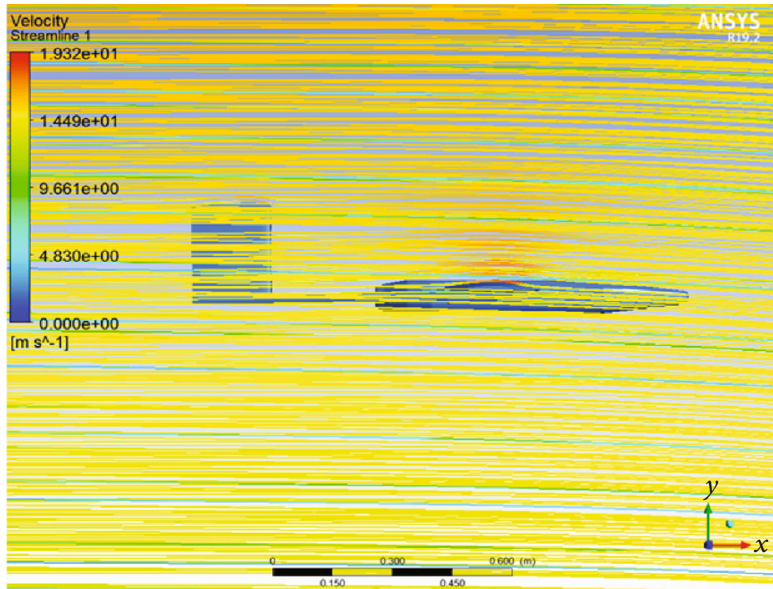

(a)

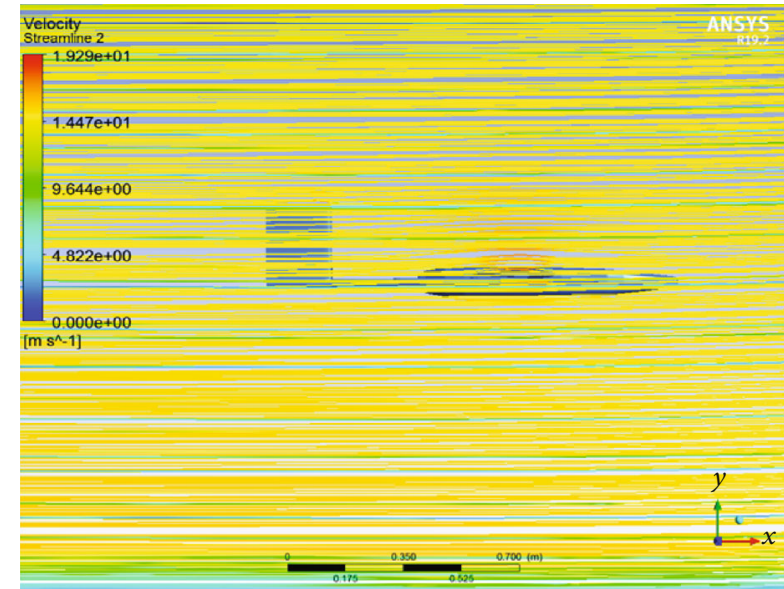

(b)

Figure 16: (a) Air flow through the aircraft at 5 deg. (b) Air flow through the aircraft at -2 deg. 


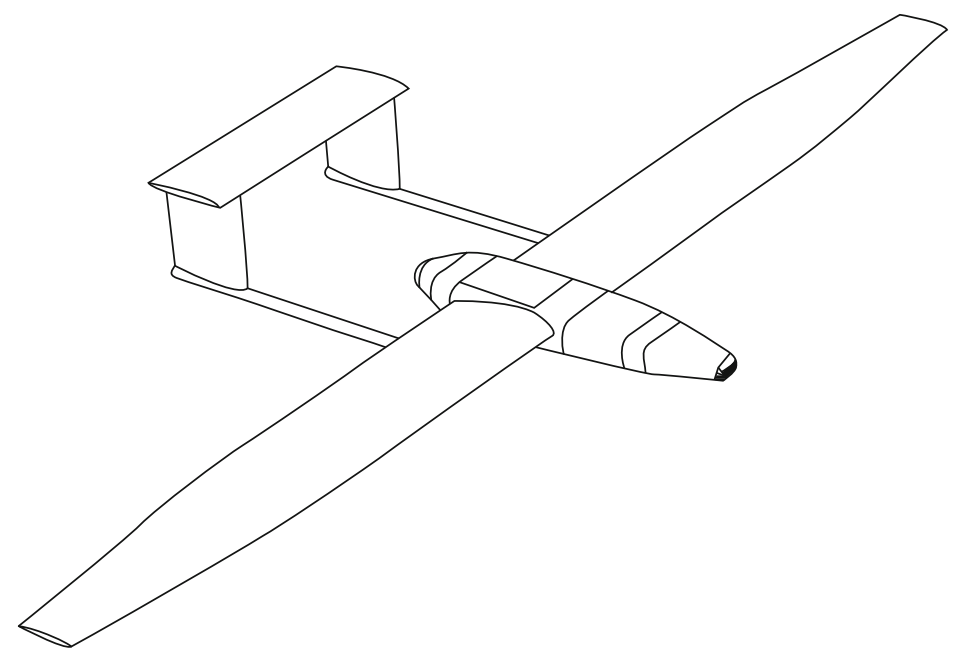

Figure 17: Final design of the UAV.

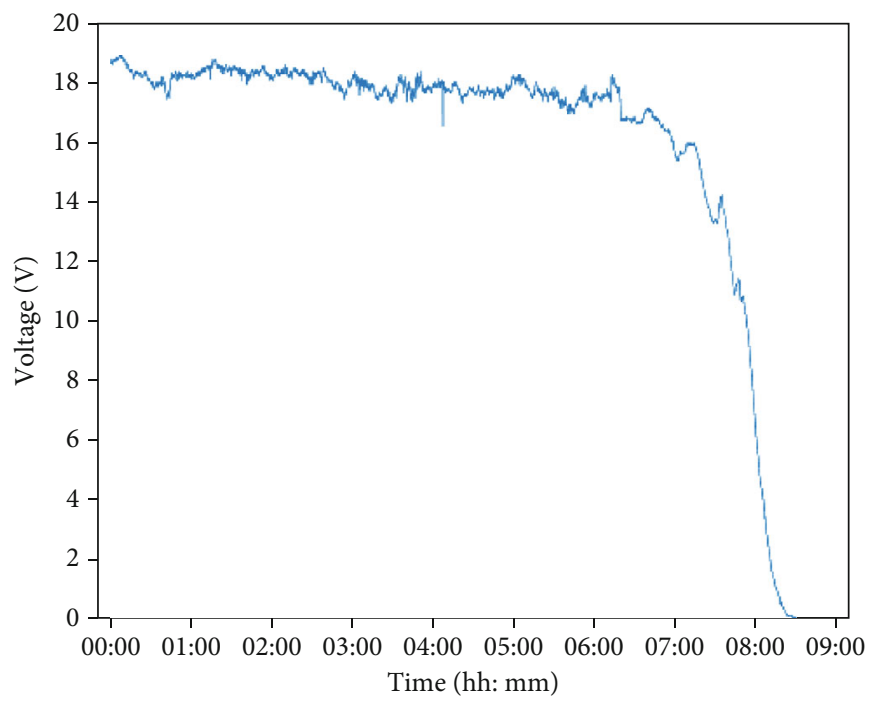

FIGURE 18: Voltage with respect to time of the solar cells.

which a maximum voltage of $19 \mathrm{~V}_{\mathrm{DC}}$ is observed and a low voltage when the sun shuts down until it reaches zero.

A charge of $37 \mathrm{k} \Omega$ was applied, which by Ohm's law gives us a current of $0.0005 \mathrm{~A}$; the experimental current with respect to time is shown in Figure 19.

In this paper, power tests are carried out using the solar cells connected as shown in Figure 20. In fact, there are two types of commercial cells, monocrystalline and polycrystalline. In [32], the authors analyze the results obtained from both solar cells over a year under semiarid conditions to determine and compare their efficiency, classifying their result based on the time of year and exposing their recommendation of polycrystalline solar cells in summer time in contrast to monocrystalline cells that provide a greater efficiency in nonsummer months. Underlying the classification, monocrystalline and polycrystalline solar cells are classified into two types, rigid and flexible. In our application, it is required to use the flexible monocrystalline cells on the extrados of the wing.

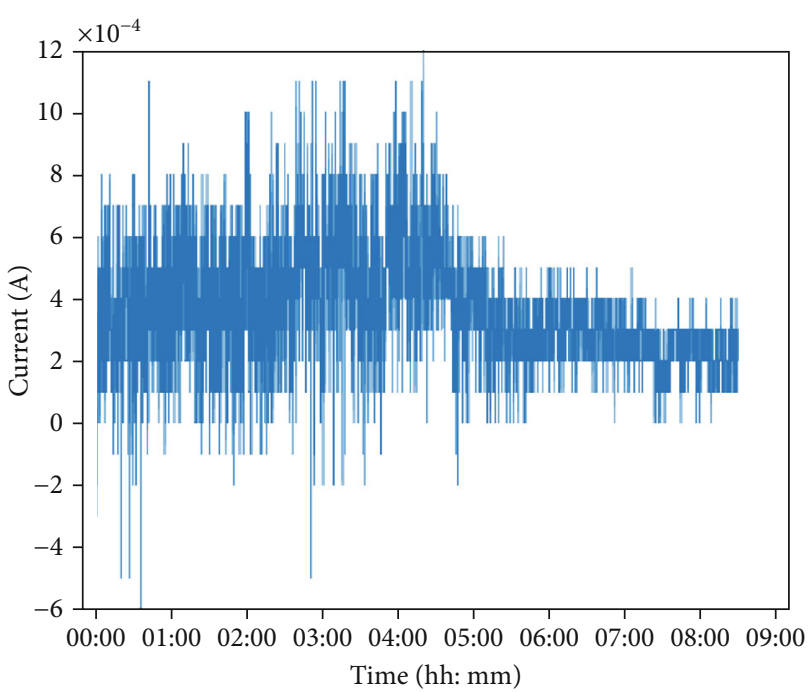

FIgURE 19: Current of the solar cells. 


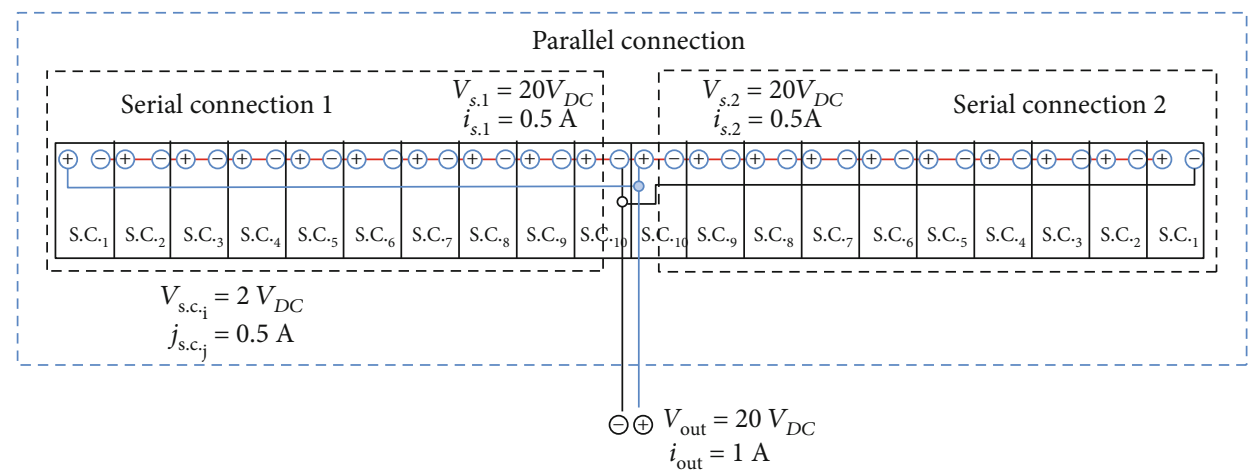

FIGURE 20: Electrical connections of solar cells.

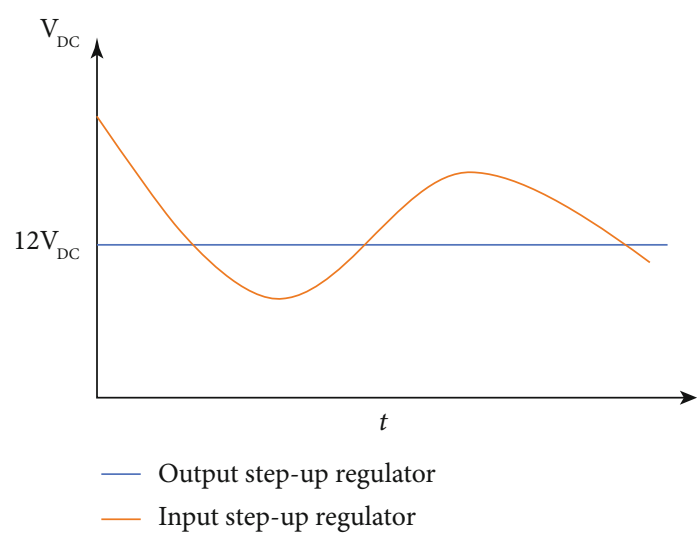

Figure 21: Voltage regulation of the step-up.

There are two types of solar cell configurations, rigid and flexible, and the construction of rigid solar cells was analized which are covered with a glass layer in order to protect the panel. In these solar cells, a thermal conductive cement substrate is applied in order to protect the solar cell that does not overheat; however, this construction provides a lot of weight for the plane in each solar cell over the wing. In this sense, the flexible solar cells have a polymer-based coating which reduces the weight and can be applied to our platform $[33,34]$.

Considering Figure 18, eight hours of constant level of voltage supplied by solar cells with an amplitude greater than $12 \mathrm{~V}_{\mathrm{DC}}$ is observed. The proposed solution in this paper when a voltage is less than $12 \mathrm{~V}_{\mathrm{DC}}$ is the use of a $12 \mathrm{~V}_{\mathrm{DC}}$ step-up regulator which guarantees the nominal voltage for the battery charger as shown in Figures 21 and 22. Sensing the battery energy, the flight time or range of the UAV is obtained based on the power consumption and battery power. In this sense, the maximum flight is estimated in order to formulate the landing time.

\section{Conclusion}

The research focuses on the conceptual, preliminary, and aerodynamic study for an unmanned aerial vehicle, designed

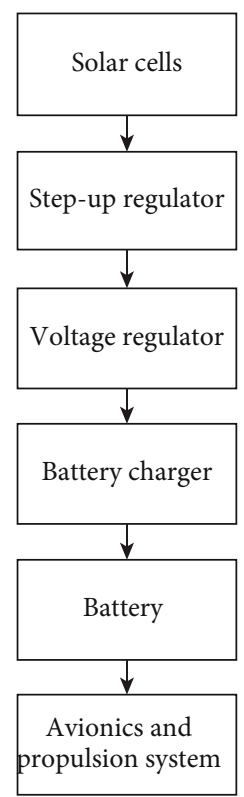

FIGURE 22: Block diagram with the step-up regulator.

under flight conditions and a specific mission. In fact, the conceptual design was made under the specifications of the area covered by the solar cells, obtaining a minimum area that the vehicle must have for the solar cells; likewise, an estimation of the weight was obtained involving all the electronic and structural elements. The empennage and fuselage were designed based on aerodynamic calculations to obtain the best glide angle which will give a static stability in the glide time. In this sense, a comparison of different airfoils was performed considering the characteristics and parameters of our platform. A preliminary model was obtained based on the conceptual design, and an aerodynamic analysis was carried out by means of computational fluid dynamics to analyze the lifting force produced by the UAV. This tool proved to be very useful for checking the design calculations that were made obtaining an aircraft capable of carrying out its flight mission. Power tests were carried out using the solar cells so that the flexible solar cells have a polymer-based coating which reduces the weight and can be applied to our platform. 


\section{Future Work}

Part of the ongoing project is to continue with the manufacture and construction of the vehicle. In this stage, the weight optimization will be considered in order to obtain the maximum performance in the gliding phase in which the solar cells will produce more energy in order to charge the battery. Having the final version of the UAV, algorithms of guidance, navigation, and control will be designed in order to perform autonomous flights.

\section{Data Availability}

The data used to support the findings of this study are available from the corresponding author upon request.

\section{Conflicts of Interest}

The authors declare that there are no conflicts of interest regarding the publication of this paper.

\section{Acknowledgments}

This research work was supported by the Institutional Fund for Regional Development of Science, Technology, and Innovation of the National Council of Science and Technology (FORDECYT-CONACYT) through the project "Strengthening of the Aeronautics in the Northeast of Mexico."

\section{References}

[1] L. R. Newcome, Unmanned Aviation: A Brief History of Unmanned Aerial Vehicles, AIAA, Reston, Virginia, 2004.

[2] T. Chang and H. Yu, "Improving Electric Powered UAVs' Endurance by Incorporating Battery Dumping Concept," Procedia Engineering, vol. 99, pp. 168-179, 2015.

[3] M. Ilarslan, M. K. Bayrakceken, and A. Arisoy, "Avionics system design of a mini VTOL UAV," IEEE Aerospace and Electronic Systems Magazine, vol. 26, no. 10, pp. 35-40, 2011.

[4] D. L. Gabriel, J. Meyer, and F. Plessis, "Brushless DC motor characterisation and selection for a fixed wing UAV," in IEEE Africon '11, pp. 13-15, Livingstone, Zambia, 2011.

[5] T. Oktay, M. Konar, M. Onay, M. Aydin, and M. A. Mohamed, "Simultaneous small UAV and autopilot system design," Aircraft Engineering and Aerospace Technology, vol. 88, no. 6, pp. 818-834, 2016.

[6] T. Oktay, M. Uzun, and O. O. Kanat, "Maximum lift/drag ratio improvement of TUAVs via small aerodynamic modifications," Aircraft Engineering and Aerospace Technology, vol. 90, no. 9, pp. 1438-1444, 2018.

[7] T. Oktay and S. Coban, "Simultaneous longitudinal and lateral flight control systems design for both passive and active morphing TUAVs," Elektronika ir Elektrotechnika, vol. 23, no. 5, 2017.

[8] P. Panagiotou, I. Tsavlidis, and K. Yakinthos, "Conceptual design of a hybrid solar MALE UAV," Aerospace Science and Technology, vol. 53, pp. 207-219, 2016.

[9] P. Rajendran and H. Smith, "Implications of longitude and latitude on the size of solar-powered UAV," Energy Conversion and Management, vol. 98, pp. 107-114, 2015.
[10] K. Reddy and A. Poondla, "Performance analysis of solar powered unmanned aerial vehicle," Renewable Energy, vol. 104, pp. 20-29, 2017.

[11] X.-Z. Gao, Z.-X. Hou, Z. Guo, J.-X. Liu, and X.-Q. Chen, "Energy management strategy for solar-powered highaltitude long-endurance aircraft," Energy Conversion and Management, vol. 70, pp. 20-30, 2013.

[12] S. Jashnani, T. R. Nada, M. Ishfaq, A. Khamker, and P. Shaholia, "Sizing and preliminary hardware testing of solar powered UAV," The Egyptian Journal of Remote Sensing and Space Science, vol. 16, no. 2, pp. 189-198, 2013.

[13] X.-Z. Gao, Z.-X. Hou, Z. Guo, R.-F. Fan, and X.-Q. Chen, “The equivalence of gravitational potential and rechargeable battery for high- altitude long-endurance solar-powered aircraft on energy storage," Energy Conversion and Management, vol. 76, pp. 986-995, 2013.

[14] X.-Z. Gao, Z.-X. Hou, Z. Guo, and X.-Q. Chen, "Reviews of methods to extract and store energy for solar-powered aircraft," Renewable and Sustainable Energy Reviews, vol. 44, pp. 96-108, 2015.

[15] J. Morgado, R. Vizinho, M. A. R. Silvestre, and J. C. Pascoa, "XFOIL vs CFD performance predictions for high lift low Reynolds number airfoils," Aerospace Science and Technology, vol. 52, pp. 207-214, 2016.

[16] K. Nordanger, R. Holdahl, T. Kvamsdal, A. M. Kvarving, and A. Rasheed, "Simulation of airflow past a 2D NACA0015 airfoil using an isogeometric incompressible Navier-Stokes solver with the Spalart-Allmaras turbulence model," Computer Methods in Applied Mechanics and Engineering, vol. 290, pp. 183-208, 2015.

[17] G. H. Yoon, “Topology optimization for turbulent flow with Spalart-Allmaras model," Computer Methods in Applied Mechanics and Engineering, vol. 303, pp. 288-311, 2016.

[18] L. M. Nicolai and G. E. Carichner, Fundamentals of Aircraft and Airship Design, American Institute of Aeronautics and Astronautics, 2010.

[19] J. T. Lowry, Performance of Light Aircraft, American Institute of Aeronautics and Astronautics, 1999.

[20] E. L. Houghton, P. W. Carpenter, S. H. Collicott, and D. T. Valentine, Aerodynamics for Enginerring Students, Butterworth-Heinemann, 7th edition, 2016.

[21] S. G. Kontogiannis and J. A. Ekaterinaris, "Design, performance evaluation and optimization of a UAV," Aerospace Science and Technology, vol. 29, no. 1, pp. 339-350, 2013.

[22] A. I. Carmona, Aerodynamics and Actuation of the Airplane, Ediciones Paraninfo-Spanish, 13th edition, 2015.

[23] R. Austin, Unmanned Aircraft Systems: UAVs Design, Development and Deployment, John Wiley \& Sons, 2011.

[24] B. Wainfan, Airfoil Selection: Understanding and Choosing Airfoils for Light Aircraft, B. Wainfan, 2005.

[25] M. H. Sadraey, Aircraft Design: A System Engineering Approach, John Wiley \& Sons, 2012.

[26] N. H. McClamroch, Steady Aircraft Flight Performance, Princeton University Press, 2011.

[27] M. V. Cook, Flight Dynamics Principles, ButterworthHeinemann, 2013.

[28] P. Rajendran and H. Smith, "Development of design methodology for a small solar-powered unmanned aerial vehicle," International Journal of Aerospace Engineering, vol. 2018, Article ID 2820717, 10 pages, 2018. 
[29] S. Morton, L. Scharber, and N. Papanikolopoulos, "Solar Powered Unmanned Aerial Vehicle for Continuous Flight: Conceptual Overview and Optimization," in 2013 IEEE International Conference on Robotics and Automation, pp. 766-771, Karlsruhe, Germany, 2013.

[30] P. Rajendran and H. Smith, "Modelling of solar irradiance and daylight duration for solar-powered UAV sizing," Energy Exploration \& Exploitation, vol. 34, no. 2, pp. 235-243, 2016.

[31] C. J. Budd, A. T. T. McRae, and C. J. Cotter, "The scaling and skewness of optimally transported meshes on the sphere," Journal of Computational Physics, vol. 375, pp. 540-564, 2018.

[32] M. Mirzaei and M. Z. Mohiabadi, "A comparative analysis of long-term field test of monocrystalline and polycrystalline PV power generation in semi-arid climate conditions," Energy for Sustainable Development, vol. 38, pp. 93-101, 2017.

[33] M. Pagliaro, G. Palmisano, and R. Ciriminna, Flexible Solar Cells, Wiley-VCH, 2008.

[34] S. Guterman, X. Wen, G. Gudavalli et al., "Optimized flexible cover films for improved conversion efficiency in thin film flexible solar cells," Optical Materials, vol. 79, pp. 243-246, 2018. 


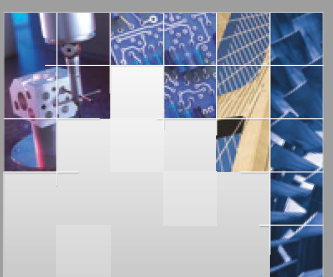

\section{Enfincering}
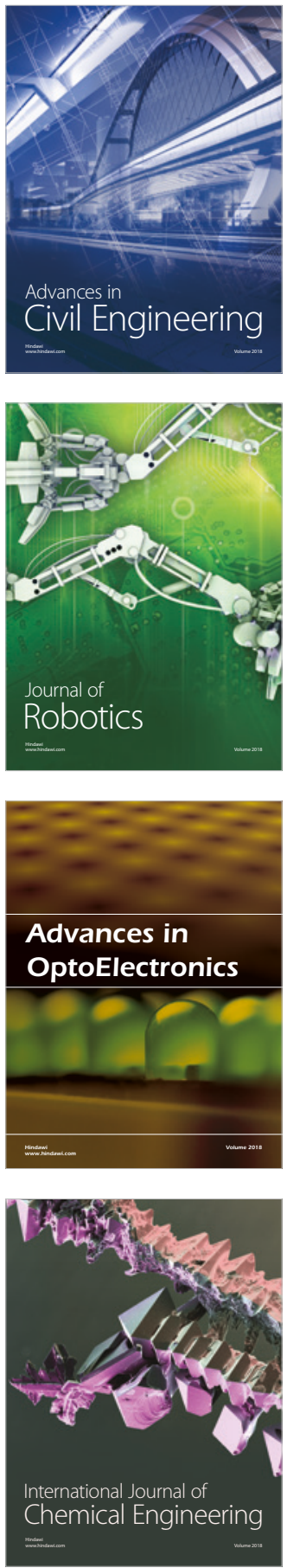

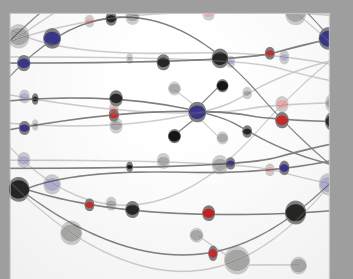

\section{Rotating \\ Machinery}

The Scientific World Journal

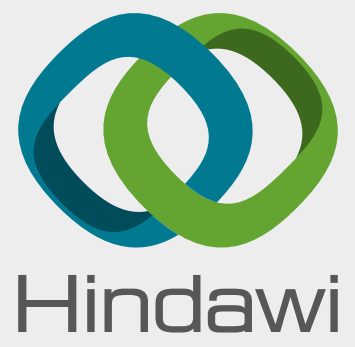

Submit your manuscripts at

www.hindawi.com
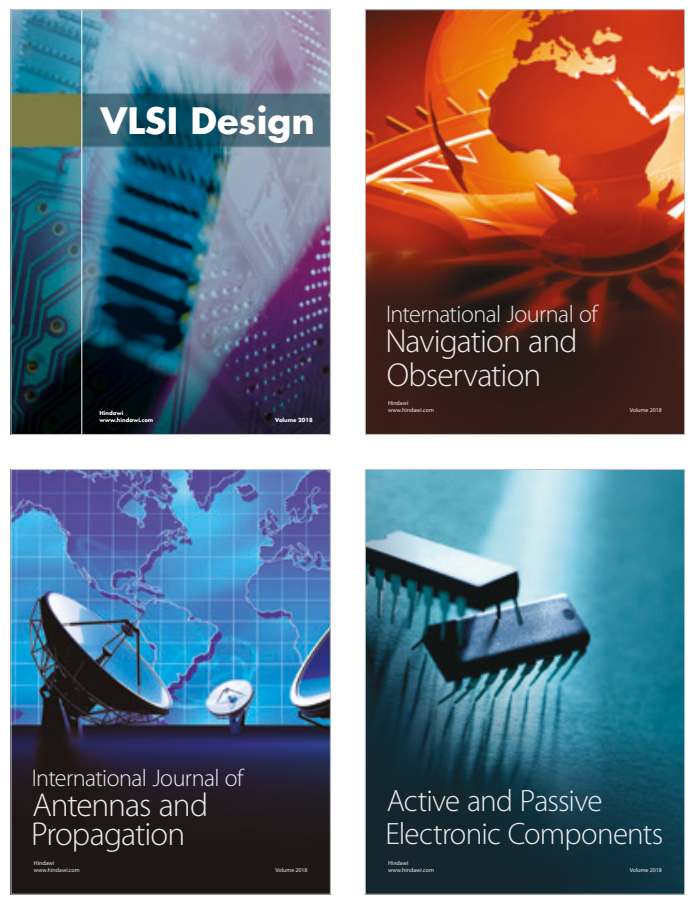
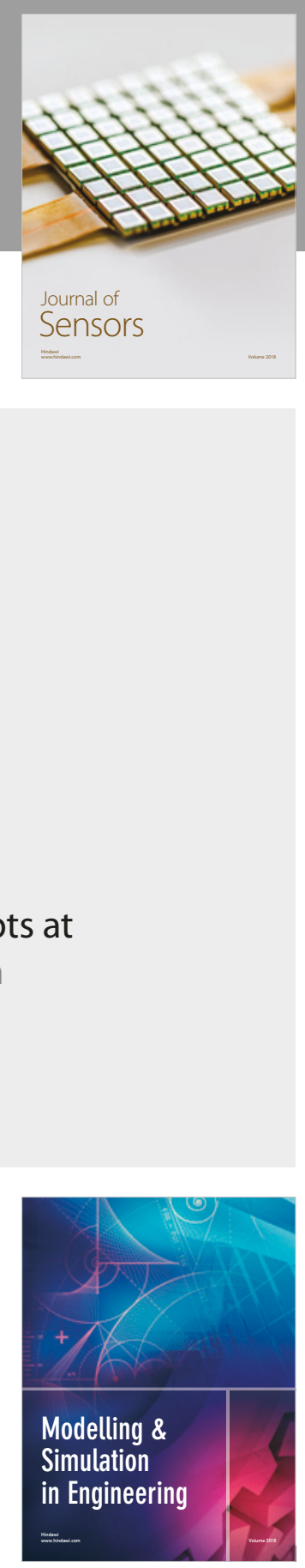

\section{Advances \\ Multimedia}
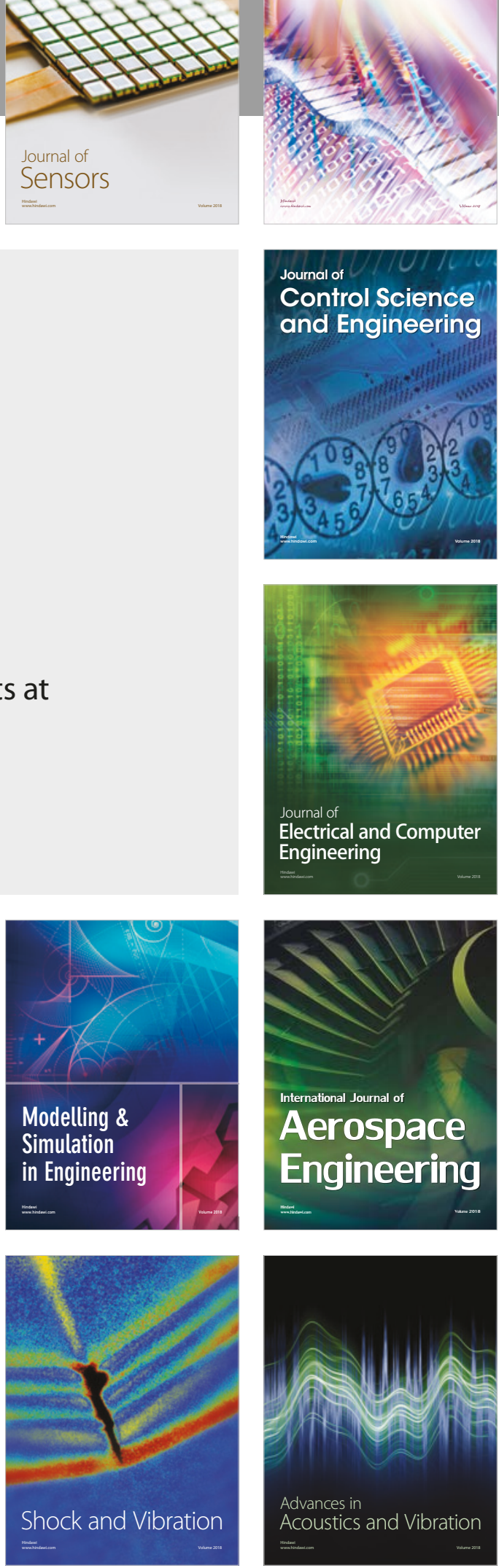